\title{
Decadal regional air quality simulations over Europe in present climate: near surface ozone sensitivity to external meteorological forcing
}

\author{
E. Katragkou ${ }^{1}$, P. Zanis ${ }^{2}$, I. Tegoulias ${ }^{2}$, D. Melas ${ }^{1}$, I. Kioutsioukis ${ }^{1}$, B. C. Krüger ${ }^{3}$, P. Huszar ${ }^{4}$, T. Halenka ${ }^{4}$, and \\ S. Rauscher ${ }^{5}$ \\ ${ }^{1}$ Laboratory of Atmospheric Physics, Aristotle University of Thessaloniki, Greece \\ ${ }^{2}$ Department of Meteorology and Climatology, Aristotle University of Thessaloniki, Greece \\ ${ }^{3}$ Institute of Meteorology, University of Natural Resources and Life Sciences, Vienna, Austria \\ ${ }^{4}$ Department of Meteorology and Environment Protection, Charles University, Prague, Czech Republic \\ ${ }^{5}$ Earth System Physics Section, The Abdus Salam International Centre for Theoretical Physics (ICTP), Trieste, Italy
}

Received: 14 April 2009 - Published in Atmos. Chem. Phys. Discuss.: 4 May 2009

Revised: 6 September 2010 - Accepted: 28 November 2010 - Published: 13 December 2010

\begin{abstract}
Regional climate-air quality decadal simulations over Europe were carried out with the RegCM3/CAMx modeling system for the time slice 1991-2000, in order to study the impact of different meteorological forcing on surface ozone. The RegCM3 regional climate model was firstly constrained by the ERA40 reanalysis dataset which is considered as an experiment with perfect meteorological boundary conditions and then it was constrained by the global circulation model ECHAM5. A number of meteorological parameters were examined including the $500 \mathrm{mb}$ geopotential height, solar radiation, temperature, cloud liquid water path, planetary boundary layer height and surface wind. The different RegCM meteorological forcing resulted in changes of near surface ozone over Europe ranging between $\pm 4 \mathrm{ppb}$ for winter and summer. The area showing the greatest sensitivity in $\mathrm{O}_{3}$ during winter is central and southern Europe while in summer central north continental Europe. The different meteorological forcing impacts on the atmospheric circulation, which in turn affects cloudiness and solar radiation, temperature, wind patterns and the meteorology depended biogenic emissions. For comparison reasons, the impact of chemical boundary conditions on surface ozone was additionally examined with a series of sensitivity studies, indicating that surface ozone changes are comparable to those caused by the different meteorological forcing. These findings suggest that,
\end{abstract}

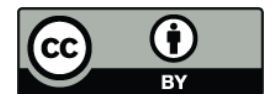

Correspondence to: E. Katragkou (katragou@auth.gr) when it comes to regional climate-air quality simulations, the selection of external meteorological forcing can be as important as the selection of adequate chemical lateral boundary conditions.

\section{Introduction}

Tropospheric ozone is an important trace gas controlling the oxidation capacity of the atmosphere with well documented adverse effects on human health (Schlink et al., 2006), agriculture (Fuhrer et al., 2003) and natural ecosystems (Scebba, et al., 2005). Tropospheric ozone chemistry includes a large set of complex photochemical reactions involving $\mathrm{NO}_{\mathrm{x}}\left(=\mathrm{NO}_{2}+\mathrm{NO}\right)$ and volatile organic compounds (VOCs) (Crutzen, 1988; Penket, 1988; Seinfeld and Pandis, 1998). Ozone precursors have natural as well as anthropogenic sources, the most important of which are emissions from soil/vegetation and fossil fuel combustion. Ambient ozone concentrations depend strongly on availability and relative abundance of those gaseous precursors but they are also modulated by the meteorological conditions (Davies et al., 1992; Kalabokas et al., 2008).

Global change including change in climate and anthropogenic emissions of $\mathrm{O}_{3}$ precursors is expected in the 21 st century (IPCC, 2007). Understanding the way that air quality is affected by changes in climate and emissions is of major importance. The direction of change is not always

Published by Copernicus Publications on behalf of the European Geosciences Union. 
clear because of multiple competing effects. There have been numerous studies on the impact of individual meteorological parameters on ozone concentrations. The parameters that are mostly found to affect ozone concentrations are temperature, solar radiation, water vapor concentration, mixing height, wind, cloud liquid water path and precipitation (Bloomfield et al., 1996; Davis et al., 1998; Sillman and Samson, 1995; Khalid and Samson, 1996; Broennimann and Neu, 1997; Baertsch-Ritter et al., 2004; Dawson et al., 2007). These parameters are not independent with each other and may have multiple effects on ozone production. Temperature, for example, alters chemical reaction rates that control the ozone budget, change PAN production, thereby affecting the $\mathrm{NO}_{\mathrm{x}}$ balance and thus ozone production and control temperature-sensitive biogenic emissions which are known to impact strongly ozone production (Fiore et al, 2005). Solar radiation also impacts on biogenic emissions directly and indirectly through temperature, since solar radiation and temperature are closely related. It is therefore a complex issue to unravel the effects of different meteorological parameters on air quality in real atmosphere because of the interdependence and the multiple feedbacks.

A more holistic approach is to study the impact of climate change on air quality which is a far more complicated task involving climate change, feedbacks with climatedependent biogenic emissions and changes in future anthropogenic emission trends. Most of the studies investigating the future air quality projections were based on global Climate-Chemistry models or global climate models coupled to chemistry-transport models (Hauglustaine et al., 2005; Stevenson et al., 2006; Racherla and Adams, 2006; Hedegaard et al., 2008; Racherla and Adams, 2008 and references therein) and only few studies give emphasis on the regional scale future air-quality (Szopa et al., 2006; Meleux et al., 2007; Nolte et al., 2008; Kruger et al., 2008).

This paper presents climate-air quality simulations over Europe on a decadal timescale with focus on the sensitivity of near surface ozone on the lateral meteorological boundary conditions constraining the climate model. This task is accomplished by performing two decadal climate-air quality simulations: the first is driven by a General Circulation Model (GCM driven control experiment) ECHAM5 (Roecker et al, 2003) and the second by the ECMWF-ERA40 reanalysis (perfect lateral boundary conditions experiment), which serves as the reference (Uppala et al., 2005). The extent to which external meteorological forcing may affect air quality simulations is of great importance especially in regard to future climate change: Comparing present GCMdriven climate simulations with reanalysis-driven simulations, we learn how sensitive are the CAMx air quality simulations to the different meteorological forcing of the perfect boundary conditions experiment and the control experiment which is a valuable information for understanding the air quality simulations in the future climate.

\section{Methodology}

\subsection{Climatic simulations}

For the climatic simulations the $\mathrm{RegCM}$ version 3 regional climate model was applied. RegCM is described by Giorgi et al. (2004a, b) and has been used for over a decade in a wide variety of applications (e.g. Giorgi and Mearns, 1999; Giorgi et al., 2006), including long term simulations over different regions of the world (e.g. Giorgi et al., 1993a, b; Small et al., 1999; Sun et al., 1999; Im et al., 2006; Seth and Rojas 2003; Francisco et al., 2006), paleoclimate simulations (Hostetler et al., 1994), climate change simulations (Giorgi et al., 1992; Hirakuchi and Giorgi, 1995; Diffenbaugh et al., 2005; Gao et al., 2006; Meleux et al, 2007), chemistryclimate interactions (Giorgi et al., 2002, 2003) and finally as part of ensembles simulations (Sanchez-Gomez et al., 2009; Rauscher et al, 2009). The dynamical core is based on the hydrostatic version of the NCAR-PSU Mesoscale Model version 5 (MM5) (Grell et al., 1994). The radiative transfer package is taken from the Community Climate Model version 3 (CCM3) (Kiehl et al., 1996). The large-scale cloud and precipitation computations are performed by Subgrid Explicit Moisture Scheme (SUBEX; Pal et al., 2000). Ocean surface fluxes are computed according to the scheme of Zeng et al. (1998) and the land surface physics according to Biosphere-Atmosphere Transfer Scheme (BATS; Dickinson et al., 1993). The adopted convective scheme for the RCM simulations in this study is the Grell scheme (Grell, 1993) with the Fritsch and Chappell (1980) closure assumption. RegCM was used to simulate the time period 19602000 for a domain covering Europe within the framework of the European project ENSEMBLES (Hewitt and Griggs, 2004). RegCM3 simulations presented in the current work cover the time period 1991-2000. The climate model was set to a spatial resolution of $50 \mathrm{~km}$ with 18 vertical layers up to $50 \mathrm{hPa}$. The dynamical time step of the model was $150 \mathrm{~s}$. Necessary meteorological variables were passed to the tropospheric gas-phase chemistry every $6 \mathrm{~h}$.

\subsection{Emissions}

Organic biogenic emissions were calculated with the use of the RegCM-CAMx interface, which extracts meteorological parameters from RegCM (temperature and radiation) and uses the available land use categories to calculate emissions (Guenther et al., 1993). Isoprene emissions were calculated according to Eq. (1).

$E_{\text {isop }}=M_{\text {isop }} f_{\mathrm{LU}} c_{\text {isop }}$

where $M_{\text {isop }}$ is the isoprene emission for a certain land-use category at a reference temperature of $30^{\circ} \mathrm{C}$ and photosynthetically active radiation of $1000 \mu \mathrm{mol} \mathrm{m}^{-2} \mathrm{~s}^{-1}$ (Simpson et al., 1999), $f_{\mathrm{LU}}$ is the land-use fraction within a model's grid box, $c_{\text {isop }}$ is the factor representing the dependence of 
isoprene emissions on temperature and radiation which is given by Eq. (2)

$$
\begin{aligned}
& \phi_{\text {isop }}=2.8782 \times 10^{-3} \mathrm{PAR} e^{\frac{9500\left(T-T_{\mathrm{r}}\right)}{2} R T T_{\mathrm{r}}} \\
& \left(\left(1+e^{\frac{2.3 \cdot 10^{5}(T-314)}{2}} R T T_{\mathrm{r}}\right) \sqrt{1+7.29 \times 10^{-6} \mathrm{PAR}^{2}}\right)
\end{aligned}
$$

where $T$ denotes temperature $(\mathrm{K}), T_{\mathrm{r}}$ is the reference temperature $(313 \mathrm{~K}), R$ the ideal gas constant and PAR the photosynthetically active radiation. Landuse was interpolated from the USGS global land-cover data. The USGS categories were than merged into four categories: coniferous forest, deciduous forest, grass cover and other (with no biogenic isoprene emissions). Monoterpenes emissions are calculated according to Eq. (1) with the respective monoterpenes emission factor $M_{\text {terp }}$ taken also by Simpson et al. (1999). The correction factor of monoterpenes is only temperature dependent and is given in Eq. (3).

$c_{\text {terp }}=e^{0.9\left(T-T_{\mathrm{r}}\right)}$

Anthropogenic emissions were calculated with data from the UNECE/EMEP data base (http://webdab.emep.int/) for European emissions (Vestreng et al., 2005) for the year 2000. These data comprise the annual sums of the emissions of $\mathrm{NO}_{\mathrm{x}}, \mathrm{CO}$, non-methane hydrocarbons, $\mathrm{SO}_{2}, \mathrm{NH}_{3}$, fine particles $(<2.5 \mu \mathrm{m})$ and coarse particles $(2.5 \mu \mathrm{m}$ to $1 \mu \mathrm{m})$ on a $50 \mathrm{~km} \times 50 \mathrm{~km}$ grid. Eleven sectors of anthropogenic activity are distinguished in accordance to SNAP97. For every sector different distributions for the month, the day of the week and the hour of the day were applied for the temporal disaggregation. The disaggregation factors are taken from the inventory by Winiwarter and Zueger (1996).

\subsection{Air quality simulations}

The air quality model simulations were performed with the comprehensive air quality model with extensions (CAMx) (ENVIRON, 2006) which is applied in the last ten years for air quality modeling studies (Lee et al., 2009, AndreaniAksoyoglu et al., 2008; Lei et al, 2007 and references therein) and climate-air quality simulations (Dawson et al., 2009). CAMx is off-line coupled to RegCM with a FORTRAN-based code interface, which reads the basic meteorological parameters from RegCM and converts them into format accepted by CAMx. These parameters include fractional landuse distribution including 11 landuse categories, three-dimensional gridded fields of height/pressure, horizontal wind components, temperature, water vapor concentrations, cloud parameters, vertical diffusivity and twodimensional surface temperature (ENVIRON, 2006).

The projection of RegCM3 and CAMx is identical (Lambert Conformal Conic) in order to avoid interpolations between grids that usually introduce large errors. The spatial resolution of CAMx, therefore, was set to $50 \mathrm{~km} \times 50 \mathrm{~km}$. The domain's vertical profile contains 12 layers of varying thickness. Layer 1 is $36 \mathrm{~m}$ deep and the uppermost layer is
$1.2 \mathrm{~km}$ thick and extends to about $6.5 \mathrm{~km}$. Top and lateral boundary conditions for all gaseous species were kept constant, with no seasonal variation and annual variability, identical for both runs. Ozone was set to $40 \mathrm{ppb}, \mathrm{NO}_{2}$ to $1 \mathrm{ppb}$ and $\mathrm{CO}$ to $200 \mathrm{ppb}$. The chemistry mechanism invoked was Carbon Bond version 4 (CB4). This mechanism includes 117 reactions -11 of which are photolytic - and up to 67 species (37 gasses, 12 radicals and up to 18 particulates). The simulations covered the period 1990-2000, with the first year used as spin-up time.

The present decade (1991-2000) was simulated twice: by ECHAM5/RegCM/CAMx as a GCM driven control experiment and by reanalysis ERA40/RegCM/CAMx as a perfect lateral boundary conditions experiment. These two runs will be referred to hereafter as ECHAM and ERA runs respectively. Since the ERA40 reanalysis project is a global atmospheric analysis of observations and satellite data streams it can be considered to be the one closer to real atmospheric conditions and thus is used as the reference run. In this work the reanalysis-driven run (ERA) is compared to the ECHAM run performed for the same decade and the differences ECHAM-ERA for the decade 1991-2000 are presented. Emphasis is given on how the different meteorological forcing affects near surface ozone, which are the dominating factors controlling ozone and what is their relevant importance for the winter and summer season.

\subsection{Statistical analysis}

In order to express in a more quantitative way the spatial relation between the seasonal changes in ozone averaged over the decade and a number of climate-dependent parameters, the Pearson correlation coefficients $R$ were calculated between $\Delta\left(\mathrm{O}_{3}\right)$ and $\Delta$ (var), where "var" the selected parameter. The selected variables were: solar radiation (SR), surface temperature $(T)$, temperature at $850 \mathrm{hPa}(\mathrm{T} 850), 500 \mathrm{hPa}$ geopotential height $(\mathrm{GH})$, wind components $(U, V)$ at the surface, planetary boundary layer height (PBL), biogenic emissions (BE) and nitrogen oxides $\left(\mathrm{NO}_{\mathrm{X}}\right)$. The significance of the calculated correlations has been evaluated with reference to the t-test. To form $t$-statistics, we computed the $t_{\text {statistic }}=$ $R\left(d f /\left(1-R^{2}\right)\right)^{1 / 2}$ and compare it with the critical values $t_{\text {critical }}$ obtained from the $t$ distribution with $d f$ degrees of freedom. The estimation of the actual number of degrees of freedom $d f$, after the effect of spatial autocorrelation has been removed, has been performed according to the formulas given in Dutilleul (1993). When $\left|t_{\text {statistic }}\right|>t_{\text {critical, the }}$ correlation was assumed locally significant.

As a next step, we established a set of independent variables that gives rise to the best prediction of $\Delta\left(\mathrm{O}_{3}\right)$. Using multiple regression analysis, $\Delta\left(\mathrm{O}_{3}\right)$ was treated as a dependant (predictant) variable and all other parameters $(\Delta(\mathrm{GH})$, $\Delta(T), \Delta(T 850), \Delta(\mathrm{SR}), \Delta(U), \Delta(V), \Delta(\mathrm{PBL}), \Delta(\mathrm{BE}))$ as independent (predictor) variables. The number of data points (cases) used in the analysis was 9200 (100 rows $\times 92$ 
columns). Stepwise multiple linear regression was used to reveal the meteorological parameters related to ozone concentration. Forward stepwise regression adds or deletes the independent variables from the model at each step of the regression until the "best" regression model is obtained. Standardized regression coefficients (beta) were taken into account. The beta value is a measure of how strongly each predictor variable influences the predicted variable. The beta is measured in units of standard deviation. The higher the beta value the greater the impact of the predictor on the predicted variable.

For the goodness of fit the adjusted $R$-square was used. $R$ is a measure of the correlation between each predictor and the criterion variable. $R$-square is the square of this measure of correlation and indicates the proportion of the variance in the predicted variable that is accounted for the statistical model. This is essentially a measure of how good is the prediction of the dependent variable knowing the predictor variables. However, $R$-square tends to somewhat over-estimate the success of the model, so an Adjusted $R$-square value is calculated which takes into account the number of variables in the model and the number of cases the model is based on. This Adjusted $R$-square value gives the most useful measure of the success of the statistical model. If, for example, the Adjusted $R$-square value is 0.75 it means that the statistical model has accounted for $75 \%$ of the variance in the predicted variable. The final step of the statistical analysis was to build a simple regression model that predicts $\Delta\left(\mathrm{O}_{3}\right)$ based on the behavior of $\Delta$ (var).

\section{Evaluation of the modeling system}

Surface ozone simulated by the RegCM3/CAMx modeling system (both ECHAM and ERA simulations) has been evaluated using measurements from the EMEP database (http:// tarantula.nilu.no/projects/ccc/network/index.html). The aim of this evaluation is to compare the simulated concentrations with the validated measurements of a European network and verify the ability of the modeling system to reproduce in an appropriate way surface ozone concentrations on a decadal average basis for different European regions.

All EMEP stations are located in rural areas and remain, thus, unaffected by local anthropogenic sources. This criterion makes the observational data suitable for validation of a regional scale model. Observations have been postprocessed and only stations meeting the $75 \%$ availability standard (within a year) were used. Stations with altitudes higher than $1500 \mathrm{~m}$ were excluded. Two measures are used to validate model performance. Modified Normalized Mean Bias (MNMB) which is selected as it treats both model deficiencies (over- and underprediction) in a symmetric manner in contrary to the normalized bias.
$\operatorname{MNMB}=\frac{2}{N} \sum_{i}^{N} \frac{M_{i}-O_{i}}{M_{i}+O_{i}}$

Fractional gross error (FGE) is used as an indicator of the overall model performance and is calculated according to Eq. (5), where $M_{i}$ corresponds to the model mean daily values and $O_{i}$ to the observed.

$\mathrm{FGE}=\frac{2}{N} \sum_{i}^{N}\left|\frac{M_{i}-O_{i}}{M_{i}+O_{i}}\right|$

Figure 1 shows daytime (08:00-16:00 UTC) surface ozone concentrations measured and simulated by CAMx (both ERA and ECHAM runs). Ozone is averaged on a country basis for the winter and summer season (left and right panels respectively). Summer is the average of months June-JulyAugust and winter of December-January-February. A total of 47 stations was used to validate the model performance and namely seven stations were used for Austria (AT), five stations for Germany (DE), seven stations for Norway (NO), ten stations for Great Britain (GB), six stations for Sweden (SE), two stations for Spain (ES), three stations for Denmark (DE), four stations for Switzerland $(\mathrm{CH})$, one station for France (1) and two stations for the Netherlands (NL). Note that Fig. 1 is indicative of the average decadal ozone concentrations appearing in each country and their deviation from the measured decadal average. A reference to the error and bias of each simulation is provided in more detail in Table 1, where the statistical measures FGE and MNMB were calculated for each season separately using daytime decadal average surface ozone concentrations.

In winter surface ozone is underestimated in both ECHAM and ERA simulations, the negative bias, however, is within acceptable limits with the only exception the station in France (FR08). This station exhibits a systematic underestimation in winter - but not in summer - with an otherwise very good temporal correlation (0.91) of mean monthly surface ozone values throughout the decade (not shown here). Although the average ECHAM and ERA decadal concentrations are comparable - decadal average differences are less than $1 \mathrm{ppb}$, the statistics (Table 1) indicate an overall better performance for the ERA simulation.

In summer the overall forecasting error is considerably lower for both simulations in comparison to wintertime. CAMx tends to overestimate ozone, especially in northern Europe and performs obviously better for central and southern Europe. The differences between the two simulations are larger in comparison to winter time, ranging from 1 to $3.5 \mathrm{ppb}$. Ozone in the ECHAM simulation gives on average lower concentrations in comparison to the ERA simulation. Additional analysis of surface ozone values using only nighttime data suggest a worse model performance during nighttime. The calculation of FGE and MNMB using $24 \mathrm{~h}$ surface ozone averages produces statistics which account for a more moderate than daytime, however, acceptable model performance. 
Table 1. Fractional gross error (FGE) and Modified Normalized Mean Bias (MNMB) for average decadal (1991-2000) daytime surface ozone concentrations for the ECHAM and ERA simulations (a) winter (DJF) (b) summer (JJA). For the country codes see text.

\begin{tabular}{lcccc}
\hline (a) WINTER & ECHAM_FGE $(\%)$ & ECHAM_MNMB (\%) & ERA_FGE $(\%)$ & ERA_MNMB (\%) \\
\hline AT & 23.1 & -4.1 & 21.2 & -9.7 \\
CH & 34.0 & 18.1 & 33.4 & 16.6 \\
DE & 27.6 & -14.1 & 22.1 & -7.3 \\
DK & 22.7 & -8.3 & 13.9 & 2.9 \\
ES & 18.5 & 10.5 & 19.0 & 12.6 \\
FR & 33.8 & -33.8 & 36.2 & -36.2 \\
GB & 35.4 & -17.6 & 24.2 & -10.7 \\
NL & 30.3 & -12.6 & 19.3 & -5.1 \\
NO & 16.1 & 1.2 & 13.7 & 6.2 \\
SE & 15.3 & -5.2 & 11.0 & -0.1 \\
\hline (b) SUMMER & ECHAM_FGE $(\%)$ & ECHAM_MNMB $(\%)$ & ERA_FGE $(\%)$ & ERA_MNMB (\%) \\
\hline AT & 12.2 & -2.9 & 9.8 & 6.6 \\
CH & 9.5 & -1.3 & 7.1 & 6.2 \\
DE & 13.9 & -1.6 & 12.6 & 8.8 \\
DK & 16.4 & 11.6 & 21.2 & 21.1 \\
ES & 8.4 & 5.3 & 9.8 & 8.4 \\
FR & 14.9 & -5.8 & 7.4 & 4.3 \\
GB & 20.3 & 15.6 & 23.9 & 22.1 \\
NL & 16.1 & 0.7 & 13.8 & 9.9 \\
NO & 22.8 & 22.0 & 26.5 & 26.3 \\
SE & 16.7 & 13.3 & 19.6 & 19.2 \\
\hline
\end{tabular}
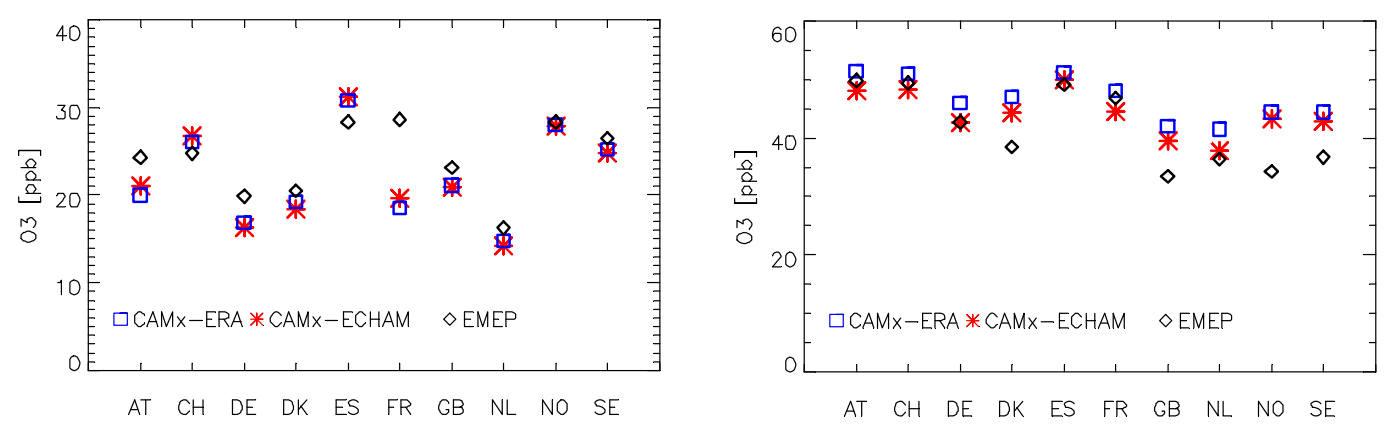

Fig. 1. Average decadal (1991-2000) surface daytime (08:00-16:00 UTC) ozone concentrations for different European counties, for winter (DJF) and summer (JJA) (left and right panels respectively). Depicted are ozone measured and simulated concentrations for both CAMx ERA and ECHAM runs. Country codes: Austria (AT), Switzerland (CH), Germany (DE), Denmark (DK), Spain (ES), France (FR), Great Britain (GB), the Netherlands, Norway (NO) and Sweden (SE).

To conclude, the evaluation analysis shows that the RegCM3/CAMx modeling system is able to reproduce average decadal surface ozone concentrations establishing it, therefore, as a suitable candidate for the examination of climate-chemistry interactions. The modeling system performs better during summer months and daytime. In summer ozone is overestimated, while the opposite is the case for wintertime, both within acceptable limits. The worst model performance in summer is located over northern Europe while in winter the situation is less homogeneous with some countries over central Europe and Great Britain exhibiting the highest errors. The greatest deficiencies of the modeling system, which are obviously mirrored in the validation results, are the space and time invariant boundary conditions affecting mostly the borders of the domain, non optimized nocturnal chemistry/processes, the same emissions for each year of the decadal simulation and the 6-hourly coupling of the meteorology and chemistry. 

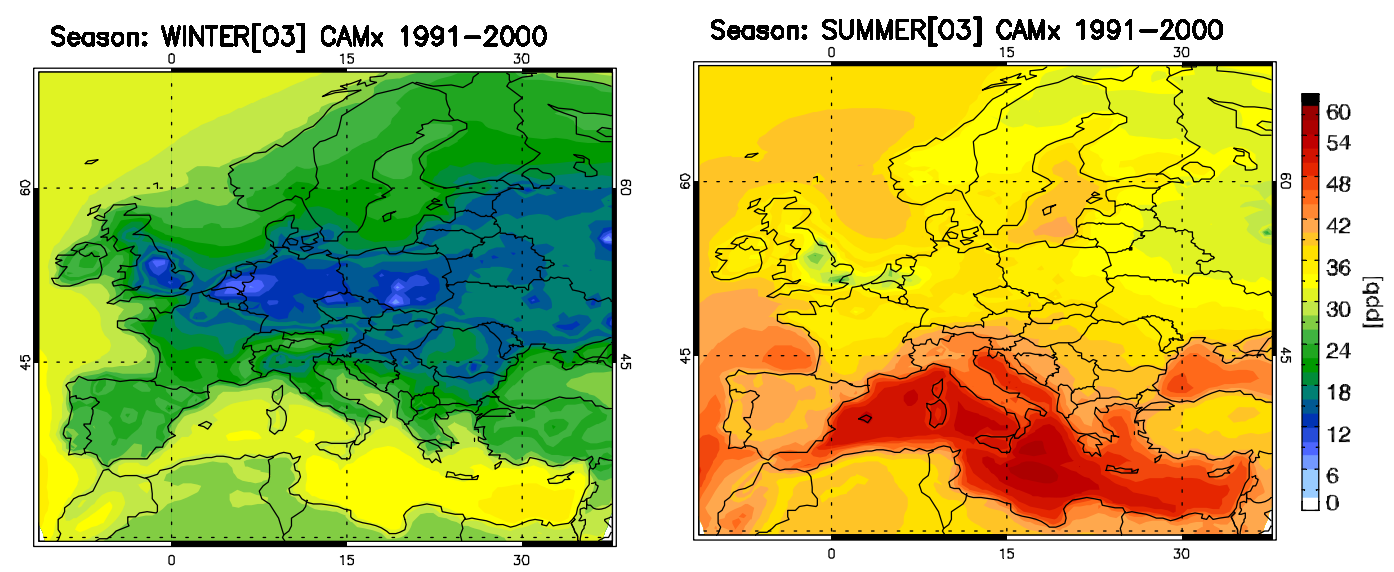

Fig. 2. Average decadal (1991-2000) surface ozone concentrations simulated by the ERA/RegCM3/CAMx modeling system for the winter (left) and the summer (right) season.

Table 2. Correlation between differences in selected variables during summer (upper triangular part) and winter (lower triangular part). All correlations are significant at the $95 \%$ level of significance. Values in bold are significant at the $99 \%$ level of significance.

\begin{tabular}{lrrrrrrrrrr}
\hline SUMMER/ & $\Delta\left(\mathrm{O}_{3}\right)$ & $\Delta(\mathrm{BE})$ & $\Delta(\mathrm{CLWP})$ & $\Delta(\mathrm{GH})$ & $\Delta(\mathrm{SR})$ & $\Delta(\mathrm{T} 850)$ & $\Delta(T)$ & $\Delta(U)$ & $\Delta(V)$ & $\Delta(\mathrm{PBL})$ \\
WINTER & & & & & & & & & & \\
\hline$\Delta\left(\mathrm{O}_{3}\right)$ & 1 & $\mathbf{0 . 4 6}$ & $\mathbf{- 0 . 5 5}$ & $\mathbf{0 . 5 7}$ & $\mathbf{0 . 5 8}$ & $\mathbf{0 . 5 5}$ & 0.36 & & & \\
$\Delta(\mathrm{BE})$ & $\mathbf{0 . 2 9}$ & 1 & -0.39 & $\mathbf{0 . 6 9}$ & $\mathbf{0 . 4 3}$ & $\mathbf{0 . 6 2}$ & $\mathbf{0 . 6 5}$ & & & $\mathbf{0 . 4 5}$ \\
$\Delta(\mathrm{CLWP})$ & & & 1 & -0.39 & $-\mathbf{0 . 7 3}$ & & & & & \\
$\Delta(\mathrm{GH})$ & & $\mathbf{0 . 3 4}$ & $\mathbf{- 0 . 5 6}$ & 1 & $\mathbf{0 . 4 6}$ & $\mathbf{0 . 9 5}$ & $\mathbf{0 . 7 0}$ & & & \\
$\Delta(\mathrm{SR})$ & & & $\mathbf{- 0 . 6 6}$ & 0.41 & 1 & 0.41 & 0.31 & & & \\
$\Delta(\mathrm{T} 850)$ & & 0.30 & $\mathbf{- 0 . 5 9}$ & $\mathbf{0 . 9 5}$ & $\mathbf{0 . 5 0}$ & 1 & $\mathbf{0 . 6 7}$ & & & \\
$\Delta(T)$ & 0.26 & $\mathbf{0 . 5 1}$ & & $\mathbf{0 . 4 6}$ & & $\mathbf{0 . 4 1}$ & 1 & $-\mathbf{0 . 5 2}$ & & $\mathbf{0 . 6 7}$ \\
$\Delta(U)$ & & & & & -0.36 & & & 1 & 0.43 & $\mathbf{- 0 . 4 4}$ \\
$\Delta(V)$ & & & & & & & $\mathbf{0 . 6 0}$ & & 1 & -0.25 \\
$\Delta(\mathrm{PBL})$ & $\mathbf{0 . 3 2}$ & $\mathbf{0 . 2 6}$ & 0.22 & & & & & 1 \\
\hline
\end{tabular}

$\mathrm{O}_{3}=$ Ozone BE $=$ Biogenic Emissions CLWP $=$ Cloud Liquid Water Path GH $=500 \mathrm{hPa}$ Geopotential Height SR = Incoming Solar Radiation $\mathrm{T} 850=850 \mathrm{hPa}$ Temperature $T=$ surface Temperature $U=$ Zonal wind component $V=$ Meridional wind component PBL $=$ Planetary Boundary Layer height

\section{Impacts of external meteorological forcing on surface ozone}

\subsection{Surface ozone}

Figure 2 shows the average decadal surface ozone concentrations as simulated by the ERA/RegCM3/CAMx modeling system. Model calculations yield higher $\mathrm{O}_{3}$ concentrations over the Mediterranean basin, attaining values of around $60 \mathrm{ppb}$ in summer and around $35 \mathrm{ppb}$ in winter. Over continental Europe the summer decadal averages range between 30 and $45 \mathrm{ppb}$ and winter decadal averages around 15-25 ppb. The surface ozone averages are calculated as the daily averages and should not be directly compared to the daytime surface ozone values plotted in Fig. 1. The average decadal winter and summer differences between ECHAM and ERA simulations in near surface $\mathrm{O}_{3}$ over Europe are shown in Fig. 3. Changes in winter are smaller, in the range of 1-2 ppb with some local maxima reaching up to $4 \mathrm{ppb}$, positive for southern and eastern Europe and negative for the north and western part of the domain. In summer ozone is lower almost over the entire domain in the ECHAM simulation, by about 2-4 ppb and mostly over the central part of continental Europe.

Figures 4-8 show ECHAM minus ERA differences in surface temperature $\Delta(T)$, incoming solar radiation $\Delta(\mathrm{SR})$, $500 \mathrm{hPa}$ geopotential height $\Delta(\mathrm{GH})$ zonal $\Delta(U)$ and meridional wind component $\Delta(V)$ and biogenic emissions $\Delta(\mathrm{BE})$. Changes in $\mathrm{O}_{3}$ concentrations are driven by changes in those variables $(\Delta$ var), caused by the different forcing (ECHAM minus ERA) - which at the same time affect the dynamics of the atmosphere, biogenic emissions and chemistry. 

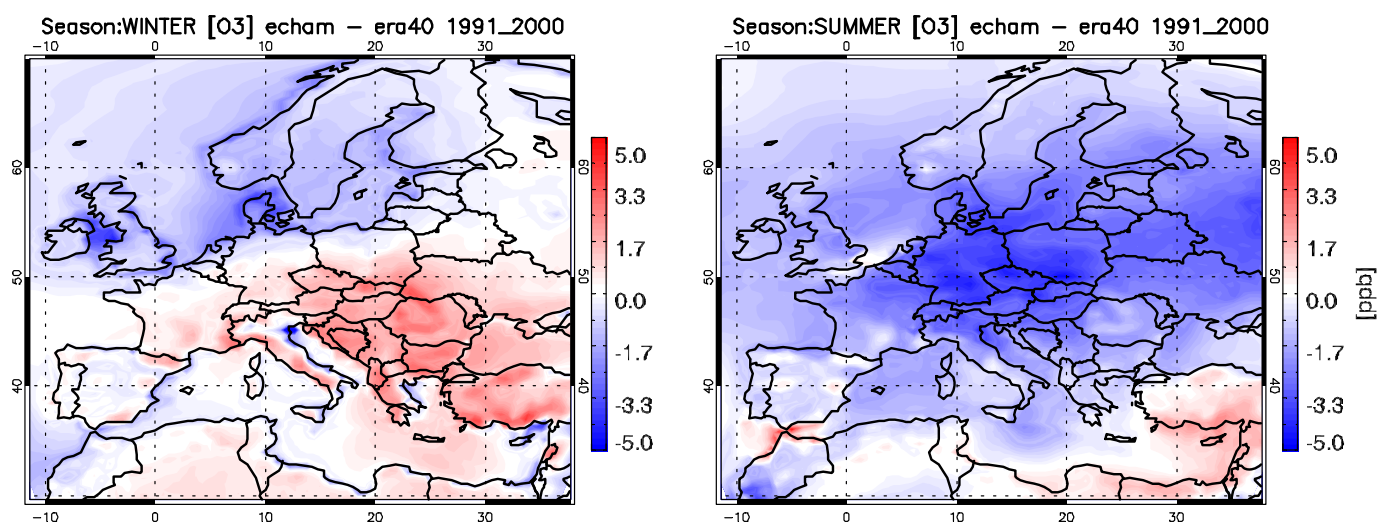

Fig. 3. Differences in simulated average surface $\mathrm{O}_{3}$ fields between the ECHAM and ERA simulations for winter (left) and summer (right) representative of the $90 \mathrm{~s}$.
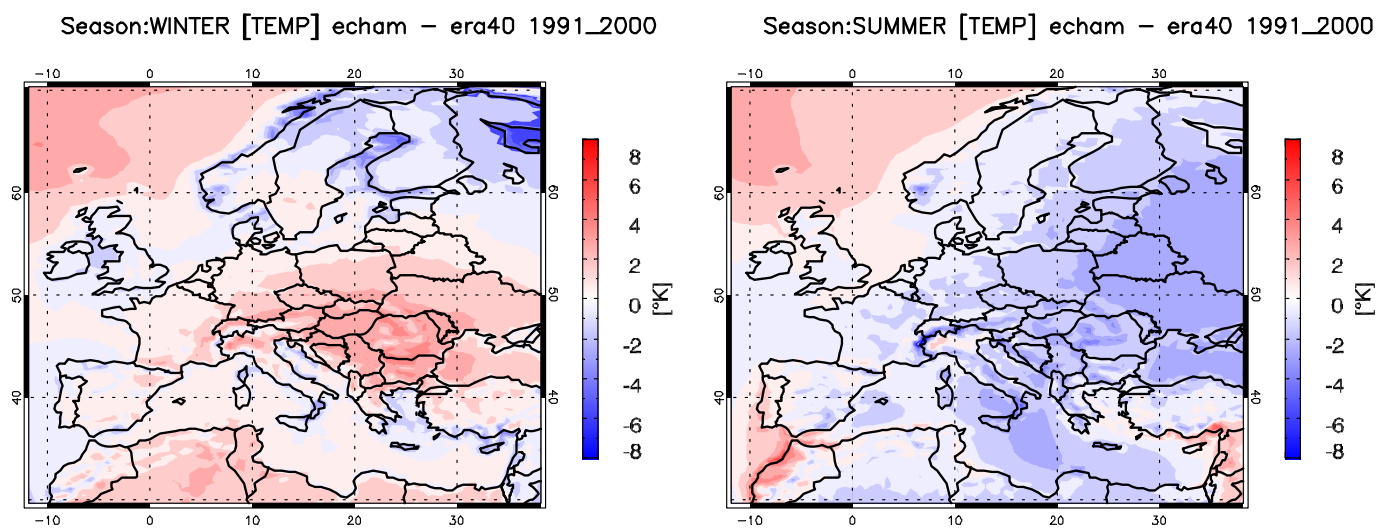

Fig. 4. Differences in simulated average surface temperature fields between the ECHAM and ERA simulations for winter (left) and summer (right) representative of the $90 \mathrm{~s}$.

The response of surface ozone to a different meteorological forcing is clear and in the following discussion we will try to identify the relative importance of several parameters that control surface ozone concentrations. Obviously, it is not easy to isolate the role of each parameter that contributes to a change in $\mathrm{O}_{3}$ fields, since they all interact in a complex way. Table 2 presents the calculated correlation coefficients between changes in $\mathrm{O}_{3}(\Delta \mathrm{O} 3)$ and changes in several variables ( $\Delta$ var). Values that are not significant to the $95 \%$ level of significance are not shown. These calculations provide a more quantitative measure of how changes in surface ozone may be related to changes in climate and climate dependent parameters.

\subsection{Temperature and PBL height}

It has been shown in several studies that temperature is a meteorological factor that greatly affects ozone in different ways. Firstly, rate constants involved in ozone chemistry are temperature dependent and secondly, biogenic emissions, which are known ozone precursors, are also temperature de- pendent. Furthermore changes in air temperature are closely related to atmospheric circulation changes, which in turn influence tropospheric ozone changes in synoptic scale (Davies et al., 1992; Kalabokas et al., 2008). In the modeling study of Dawson et al. (2007), which investigated the impact of several meteorological parameters on ozone, it was shown that of all parameters, the one having the largest impact on ozone was temperature. Ozone exceedances and average daily maximum $8 \mathrm{~h}$ concentrations increased almost linearly with temperature. PAN chemistry was found to be largely responsible for the dependence of ozone formation on temperature. Meleux et al., 2007 in their study of summer European ozone reported that temperature driven increase in biogenic emissions appeared to enhance ozone production and isoprene was identified to be the most important chemical factor in the ozone sensitivity. The same conclusion was reached by Hedegaard et al. (2008) with their modeling study of climate change on air pollution, suggesting that dominating impacts on a large number of species including ozone are related to temperature increase. 

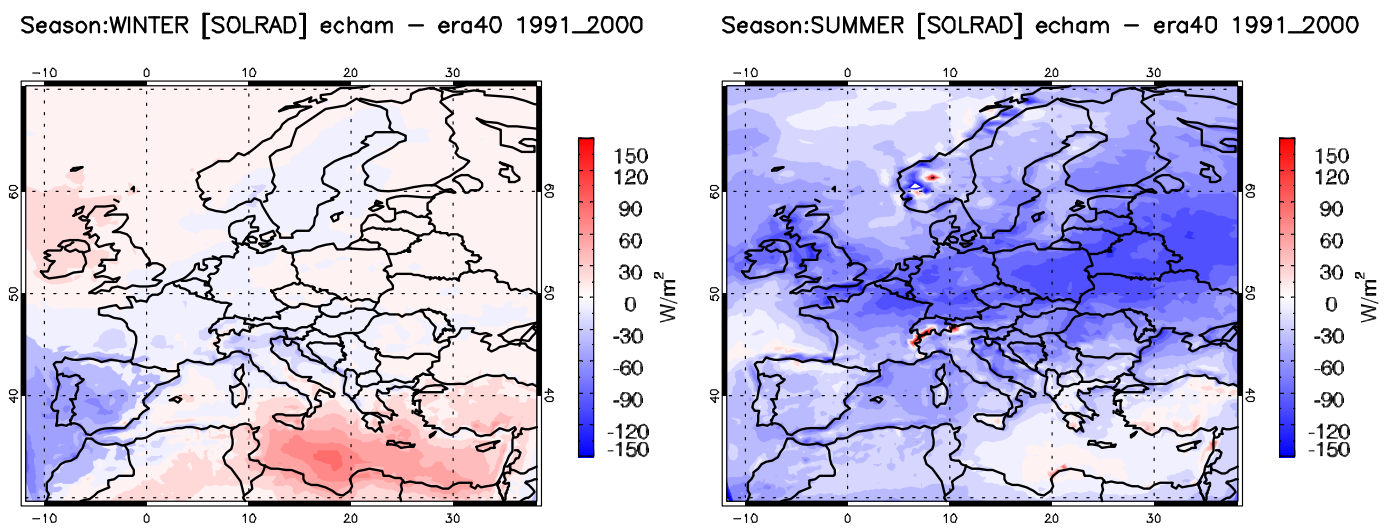

Fig. 5. Differences in simulated average incoming solar radiation fields between the ECHAM and ERA simulations for winter (left) and summer (right) representative of the $90 \mathrm{~s}$.

Figure 4 (left panel) shows differences in near surface air temperature between the ECHAM and ERA run during winter. Fields of $\Delta\left(\mathrm{O}_{3}\right)$ bare some similarities to $\Delta(T)$ : ECHAM runs yielded higher temperatures over Europe mainland up to 4 degrees and higher ozone concentrations with similar spatial pattern up to $4 \mathrm{ppb}$. Mind that the highest positive temperature differences seen over centraleastern and south-eastern Europe collocate with the highest positive ozone differences. Similar temperature-ozone spatial patterns with the same sign are also observed over Asia minor and N. Africa, UK and part of the Scandinavian peninsula. In contrast, the increase of temperature of about $2-3 \mathrm{~K}$ over the north-west corner of the domain does not appear to be followed by an ozone increase.

The pattern of temperature changes between ECHAM and ERA is quite different in summer. The field of $\Delta(T)$ is mostly negative with the exception of north- and south-west and south-east corners of the domain. Interestingly, the more intense decrease of temperature over central Mediterranean can be also observed in $\mathrm{O}_{3}$ summer average field. On the contrary, the stronger decrease of $\mathrm{O}_{3}$ in summer over central Europe does not seem to be explained by temperature changes. Overall, the correlation coefficient between $\Delta\left(\mathrm{O}_{3}\right)$ and $\Delta(T)$ are statistical significant over the whole domain: 0.26 in winter and 0.36 in summer (Table 2).

The changes in planetary boundary layer height (PBL) averaged over the decade 1991-2000 for winter and summer (not shown) are such that lower PBL is seen in winter over the Mediterranean, Scandinavia and the UK, and in summer over all parts of continental Europe in the ECHAM simulation. Maximum $\Delta(\mathrm{PBL})$ is about $500 \mathrm{~m}$. As seen in Table 2, changes in PBL are mostly related to changes in temperature $(R=0.6$ in winter and 0.67 in summer both significant at the $99 \%$ level), indicating that higher temperatures support the evolution of higher PBL.

\subsection{Solar radiation and cloud liquid water path}

Solar radiation is naturally expected to strongly affect ozone since it controls all photochemical reactions which are involved in ozone production and destruction processes. According to Krüger et al., 2008 increase of net radiation together with temperature are expected to increase ozone concentrations by the end of the century. Comparison of Figs. 3 and 5 , which depict $\Delta\left(\mathrm{O}_{3}\right)$ and $\Delta(\mathrm{SR})$ respectively, shows that the correlation between solar radiation and surface ozone is clearly stronger in summer than in winter season, when actually is found to be statistically insignificant. Calculation of the correlation coefficient between the two fields yields a relatively good correlation of 0.58 in summer (Table 2). The main ozone decrease of surface ozone in the ECHAM run in central Europe seems to be related to the decrease of solar radiation. The relation of the two fields is easily understood since ozone production is photochemically driven and thus sun-light dependent.

There is a good agreement between $\Delta$ (CLWP) (not shown) and $\Delta(\mathrm{SR})$ fields. Increase of CLPW is accompanied by a decrease in solar radiation. In Table 2 it is shown that there is a significant anti-correlation between CLWP and SR, which ranges from -0.66 in winter to -0.73 in summer. Specifically, in summer, the decrease of solar radiation in the ECHAM run in comparison to ERA is a result of increased cloudiness over Europe in a latitude belt extending from $45^{\circ}$ to $65^{\circ}$. Furthermore, the dipole pattern of SR increase in Eastern Mediterranean and SR decrease over the Iberian Peninsula and adjacent Atlantic Ocean in winter is associated with an anti-correlated dipole pattern in CLPW differences. These differences in cloudiness indicate differences in atmospheric circulation over Europe between ECHAM and ERA simulations and they are discussed more extensively below. 


\subsection{Geopotential height and wind}

It is known that atmospheric circulation exerts important influence on the distribution of ozone and its precursors on various scales. Hegarty et al., 2007 showed that certain circulation patterns over northeastern United States, identified with a correlation-based synoptic categorization technique, controlled summertime surface ozone. The $500 \mathrm{mb}$ geopotential height as well as the zonal and meridional wind components are used as indicators for identifying the synoptic scale circulation differences between ECHAM and ERA simulations (Figs. 6 and 7).

The average 1991-2000 winter ECHAM circulation pattern has a steeper geopotential height gradient along Europe, being more anticyclonic over eastern Europe and more cyclonic over west Europe-east Atlantic. The more anticyclonic conditions over eastern Europe are expected to be accompanied with fairer weather conditions, higher temperature, lower cloudiness and higher surface solar radiation levels. These geopotential height differences in winter (Fig. 6, left panel) are associated strongly to temperature at $850 \mathrm{hPa}$ ( $R=0.95$ ) and surface temperature (the $R=0.46$ ) both at the $99 \%$ level of significance, cloudiness $(R=0.56$ at the $99 \%$ level of significance) and solar radiation $(R=0.41$ at the $95 \%$ level of significance). All these parameters support the build up of high ozone concentrations as well as its photochemical production in winter. Indeed, ozone concentrations are higher in winter over eastern Europe and decrease over eastern Atlantic where geopotential heights are lower, probably related to more cyclonic conditions.

The pattern of the geopotential height differences in winter is supported by the respective pattern of differences in zonal and meridional wind components (Fig. 7). Westerlies over the Iberian Peninsula become stronger in ECHAM than in ERA simulations and weaker over northern UK and North Atlantic Ocean while the meridional wind component is characterized by an increased southern zonal flow in ECHAM with its maximum over Germany and Poland. These induced wind changes are expected as a result of the more cyclonic conditions over west Europe-east Atlantic and the more anticyclonic conditions over eastern Europe.

The field of the $500 \mathrm{hPa}$ GH differences between ECHAM and ERA simulations in summer shows a low over Russia of about $-50 \mathrm{~m}$. This feature implies a more cyclonic behavior of ECHAM in the region between $50-55^{\circ}$ latitude and $25-40^{\circ}$ longitude which is expected to be accompanied with typical cyclonic patterns, i.e. lower temperatures, increased cloudiness and reduced solar radiation. These features are indeed encountered in $\Delta(T)$ (Fig. 4) and $\Delta($ SR) fields. The correlation coefficient between $\Delta\left(\mathrm{O}_{3}\right)$ and $\Delta(\mathrm{GH})$ is 0.57 and significant at the $99 \%$ level in summer, suggesting that atmospheric circulation impacts on surface ozone concentrations, either directly through atmospheric circulation or indirectly through photochemistry. The average difference map of wind components for the summer period shows enhanced westerly winds in mid-latitudes for the ECHAM run (Fig. 7) related to higher West-East GH gradient. A stronger north meridional component is also apparent mainly over Scandinavia, which is associated with the low seen over Russia in the map of $\Delta \mathrm{GH}$. Obviously the wind components agree well with the synoptic circulation features as seen through the $\Delta(\mathrm{GH})$ fields.

\subsection{Biogenic emissions}

Biogenic emissions (BE) are known to have a strong impact on surface ozone concentration. The most important biogenic hydrocarbon in atmospheric chemistry is isoprene $\left(\mathrm{C}_{5} \mathrm{H}_{8}\right)$ (Seinfeld and Pandis, 1998). The relative magnitudes of isoprene and $\mathrm{NO}_{\mathrm{x}}$ emissions determine the impact on $\mathrm{O}_{3}$ (Fiore et al., 2005). Isoprene oxidation is a large source of hydroperoxy $\left(\mathrm{HO}_{2}\right)$ and organic peroxy radicals $\left(\mathrm{RO}_{2}\right)$, which can react with $\mathrm{NO}_{\mathrm{x}}$ to stimulate $\mathrm{O}_{3}$ production. In rural areas, especially where $\mathrm{NO}_{\mathrm{x}}$ is low, however, $\mathrm{O}_{3}$ production is considered as $\mathrm{NO}_{\mathrm{x}}$-sensitive and insensitive to VOCs. Under low $\mathrm{NO}_{\mathrm{x}}$ emissions, high isoprene emissions can even decrease $\mathrm{O}_{3}$ by either sequestering $\mathrm{NO}_{x}$ as isoprene nitrates, thereby suppressing $\mathrm{O}_{3}$ formation or by ozonolysis of isoprene. The treatment of isoprene chemistry by chemical mechanisms of global and regional models has still great uncertainties and their impact on $\mathrm{O}_{3}$ budget is large. The study of von Kuhlmann et al. (2004) suggested that the relative differences in ozone mixing ratio for different isoprene oxidation schemes can be up to $30-60 \%$. Recently, Ito et al. (2009) also showed that increasing the degree of recycling of $\mathrm{NO}_{\mathrm{x}}$ from isoprene nitrates in isoprene oxidation scheme has large impact on tropospheric ozone.

The modeling results suggest a small but significant impact of biogenic emission changes on surface ozone during winter. The impact is small due to the fact that biogenic emissions are low in winter months. The small increase of BE over the Balkan Peninsula in the ECHAM run (Fig. 8) is probably related to the temperature increase as indicated also by the higher positive correlation between $\Delta(\mathrm{BE})$ and $\Delta(T)$ (0.51). Biogenic emissions are lower for the ECHAM run during summer, due to the mostly negative $\Delta(\mathrm{SR})$ and $\Delta(T)$ fields. Temperature increases in the southern east and west corners of the domain lead to higher biogenic emissions in ECHAM. The correlation of $\Delta(\mathrm{BE})$ and $\Delta\left(\mathrm{O}_{3}\right)$ fields during summer is higher (0.46) implying a stronger dependence of ozone on emissions of biogenic origin during warm months.

\subsection{Multiple linear regression analysis}

In order to assess to which extent changes in the selected meteorological variables explain the changes in surface ozone concentrations between ECHAM and ERA simulations, we built a simple regression model using as independent variables all the variables listed in Table 3 and as dependent variable the difference in surface ozone between the ECHAM 

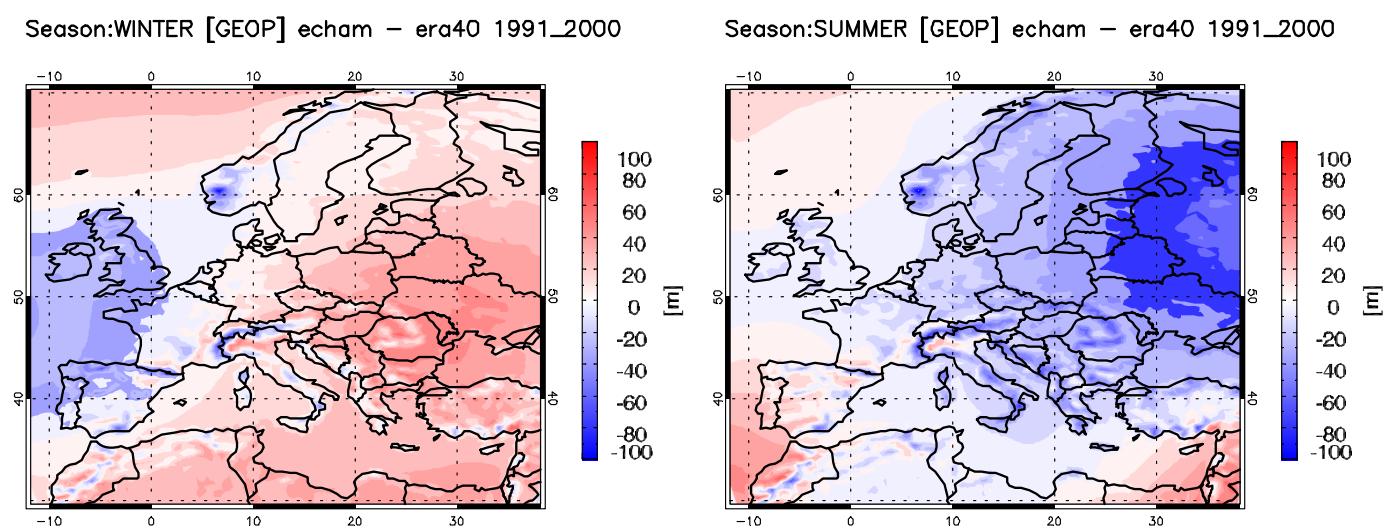

Fig. 6. Differences in simulated average $500 \mathrm{hPa}$ geopotential height fields between the ECHAM and ERA simulations for winter (left) and summer (right) representative of the $90 \mathrm{~s}$.

Season:WINTER [U] echam - era40 1991_2000

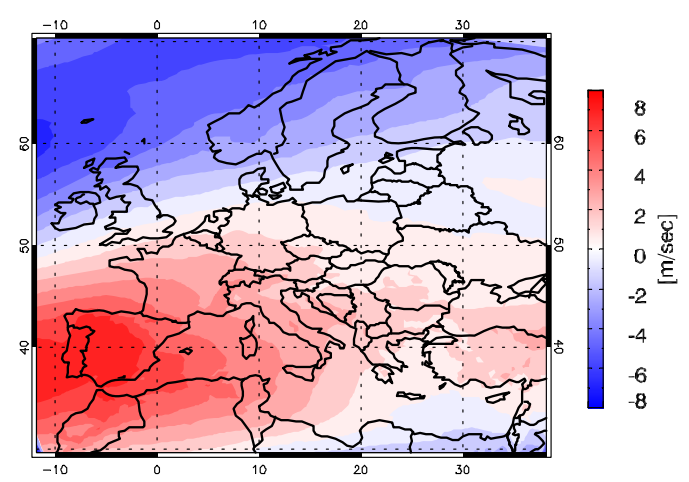

Season:WINTER [V] echam - era40 1991_2000

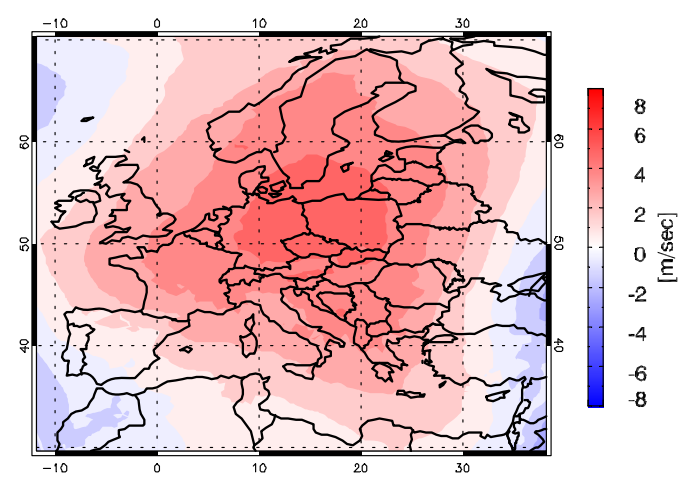

Season:SUMMER [U] echam - era40 1991_2000

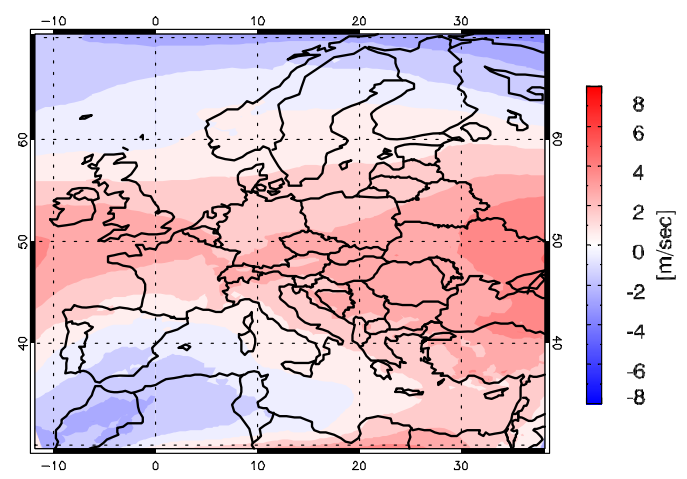

Season:SUMMER [V] echam - era40 1991_2000

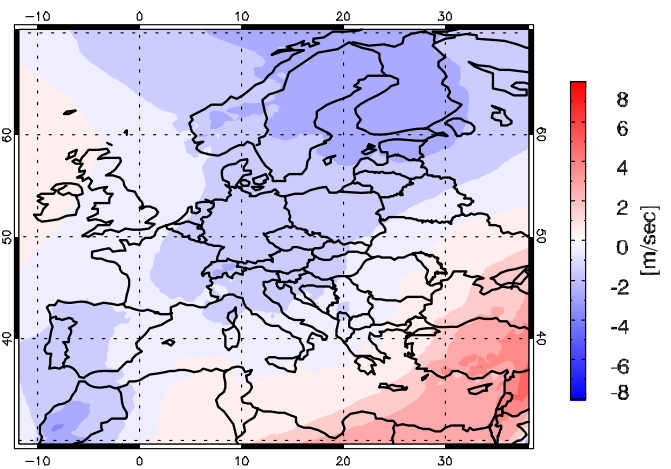

Fig. 7. Differences in simulated average meridional ( $U$ upper panel) and zonal ( $V$ bottom panel) wind component fields between the ECHAM and ERA simulations for winter (left) and summer (right) representative of the $90 \mathrm{~s}$.

and ERA simulations. Adjusted $R$-square is presented at the bottom of Table $3 \mathrm{a}$ and $\mathrm{b}$, for winter and summer respectively, together with the statistical significance of the results. The first column of each table shows the $R$-square change for every variable, which is a measure of how the power of the regression model changes with the addition or removal of a predictor variable. The second column shows the beta value for each variable examined.

The results of our simple statistical model suggest that the changes in surface ozone can be predicted better during summer than during winter, knowing only the changes in meteorological variables. The statistical model succeeds to account 

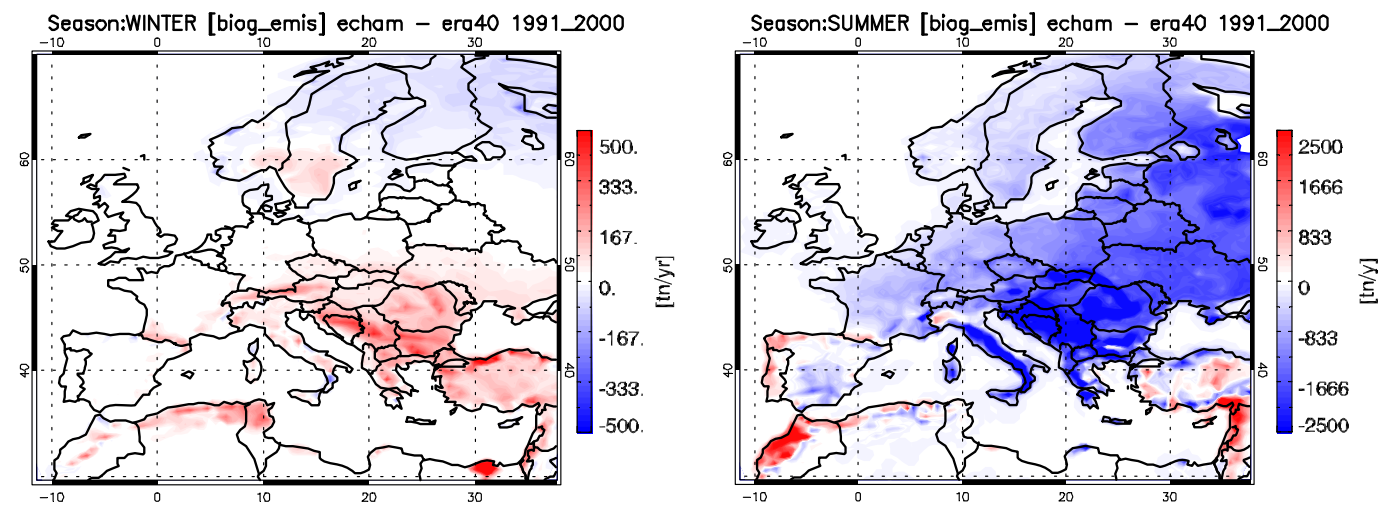

Fig. 8. Differences in simulated average biogenic emissions between the ECHAM and ERA for winter (left) and summer (right) representative of the $90 \mathrm{~s}$. Mind the differences in color scales for the two seasons.
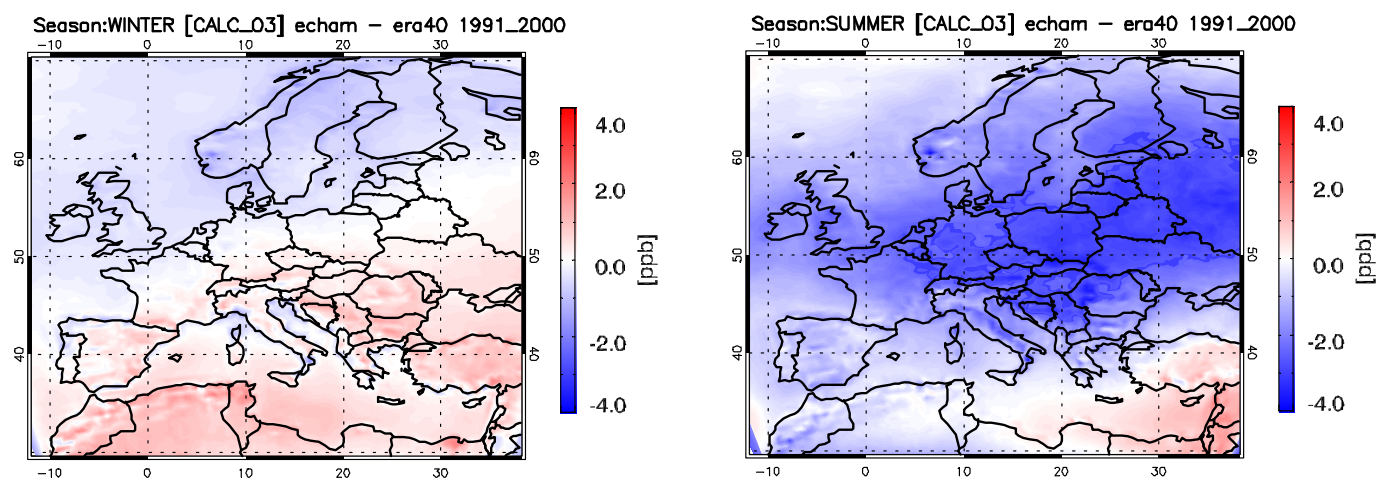

Fig. 9. Average surface $\mathrm{O}_{3}$ fields calculated from the regression model for winter (left) and summer (right).

for $62 \%$ of the variance in the predicted variable in summer and up to $26 \%$ in winter. The inclusion of solar radiation explains a $33 \%$ of the $\Delta\left(\mathrm{O}_{3}\right)$ variance followed by geopotential height which explains almost $12 \%$ in warm months.

Figure 9 illustrates the predicted $\Delta\left(\mathrm{O}_{3}\right)$ values as calculated by the simple regression model and it is indicative of the impact of changes in meteorological parameters and the climate-dependent biogenic emissions on the absolute magnitude and spatial pattern changes of surface $\mathrm{O}_{3}$. Comparison of Figs. 3 and 9 shows that the summer surface ozone decrease over Europe in the ECHAM simulation is mainly explained by the changes in meteorology. The features of surface $\Delta\left(\mathrm{O}_{3}\right)$ appearing in Fig. 3 over the area of Gibraltar and the English Channel could be attributed to the changes in $\mathrm{NO}_{\mathrm{x}}$ concentrations, which are also expected to change slightly due to the temperature-dependent shifted balance of nitrogen species. The statistical model reproduces the basic spatial pattern of the winter surface ozone changes, with the increase over southern and eastern Europe and the decrease over Scandinavia and Great Britain. The greatest ozone decreases over the Irish Sea, Denmark, the east Italian coast along the Adriatic, and the area over Gibraltar, could be attributed to chemistry related processes.

\subsection{Sensitivity to chemical boundary conditions}

In order to assess the impact of chemical boundary conditions on the concentrations of surface ozone and compare with sensitivity in meteorological forcing, four sensitivity studies were performed including the impact of both top and lateral boundary conditions. The assumption of constant top boundaries implies that important processes such as stratosphere-troposphere exchange and intercontinental transport of pollutants are not taken into consideration. According to Tang et al. (2007) top boundary conditions show strong effect on $\mathrm{O}_{3}$ predictions above $4 \mathrm{~km}$. From global studies (Stevenson et al., 2006) it is known that stratospheric flux to the troposphere is an important contribution to the global ozone budget and that in future projections upper tropospheric ozone will rise, especially in the Northern Hemisphere, which is related to an increased influx from the stratosphere. However, in these global studies the effect of stratospheric influx to the surface ozone (the focus of this study) is expected to be smaller. With respect to intercontinental transport of pollution towards Europe, Li et al. (2002) showed that the effects of North America and Asia anthropogenic emissions on European surface ozone is on average over summer 

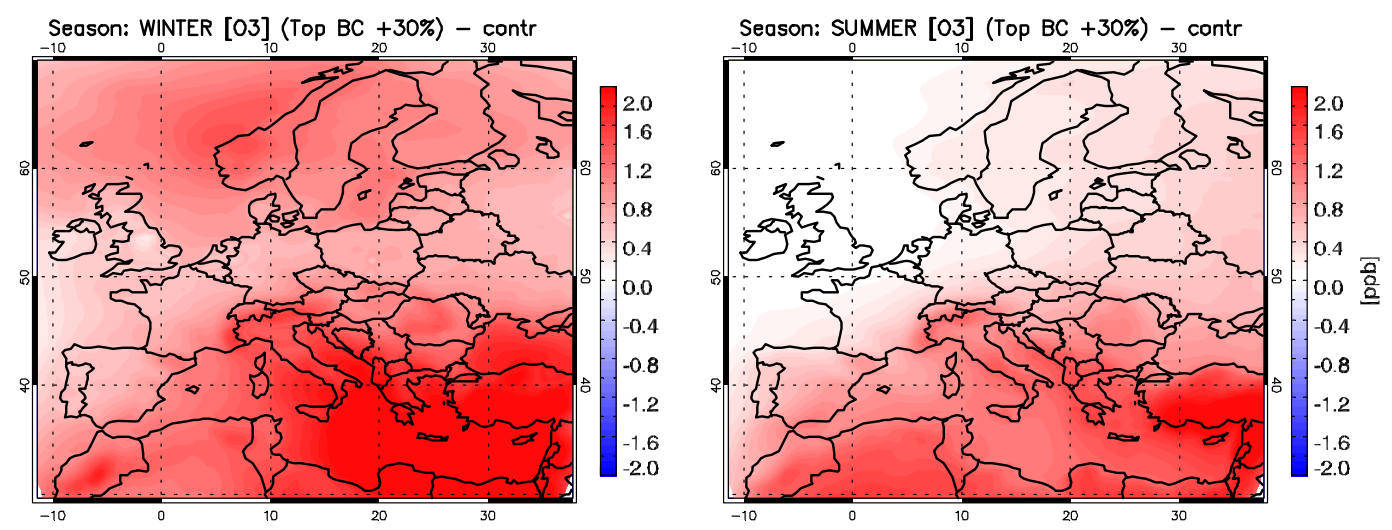

Fig. 10. Sensitivity study with $30 \% \mathrm{O}_{3}$ increase in the top boundary conditions. The plots show changes in seasonal average surface ozone concentrations for the winter (left) and the summer (right) season.

Table 3.

(a) Multiple regression analysis results for the winter period

\begin{tabular}{lcc}
\hline$\Delta$ (var) & $R$-square change & Beta \\
\hline GH & 0.0846 & 0.583 \\
$U$ & 0.0817 & 0.321 \\
SR & 0.0234 & 0.260 \\
T850 & 0.0260 & -0.469 \\
$T$ & 0.0194 & 0.115 \\
$V$ & 0.0192 & -0.158 \\
BE & 0.0090 & 0.117 \\
\hline
\end{tabular}

Adjusted $R$-square $0.263, p=0.00$

(b) Multiple regression analysis results for the summer period

\begin{tabular}{lcc}
\hline$\Delta$ (var) & $R$-square change & Beta \\
SR & 0.333 & 0.159 \\
GH & 0.119 & -0.210 \\
$V$ & 0.066 & 0.436 \\
$U$ & 0.053 & -0.290 \\
CLWP & 0.030 & -0.260 \\
BE & 0.009 & 0.185 \\
T850 & 0.010 & 0.334 \\
PBL & 0.004 & -0.090 \\
$T$ & 0.0002 & 0.032 \\
\hline
\end{tabular}

Adjusted $R$-square $0.623, p=0.00$

1997 around $2-3$ ppbv for the largest part of Europe. This is rather small compared to the effect of the European emissions on European surface ozone which is more than $20 \mathrm{ppbv}$. The sensitivity studies of chemical boundaries performed in this work include (i) a $30 \%$ (12 ppb) increase of $\mathrm{O}_{3}$ top boundary (ii) a $5 \%$ (2 ppb) increase of $\mathrm{O}_{3}$ lateral boundaries (iii) a $20 \%$ increase of $\mathrm{O}_{3}(8 \mathrm{ppb})$ lateral boundaries and (iv) a $50 \%$ increase of $\mathrm{NO}_{\mathrm{x}}(1 \mathrm{ppb})$ lateral boundaries.

\subsection{Impact of ozone top boundaries on surface ozone}

Figure 10 depicts the impact of a 30\% (12 ppb) increase of ozone top boundaries on surface ozone for the winter and summer season. The changes over the whole European domain for both seasons is less than $2 \mathrm{ppb}$. In winter the area mostly affected is the Mediterranean and to a lesser extent the northern part of the domain over east Atlantic. During the summer period the impact is even lower and restricted over the Mediterranean. This behavior can be attributed to the circulation features which come about as a result of high and low pressure areas of the midlatitudes: The high pressures at $\sim 30^{\circ}$ support descent of air masses from higher altitudes to Earth's surface leading therefore to increase of the top boundary $\mathrm{O}_{3}$ richer air masses to the surface in the southern part of our domain. This finding is also in according with the climatological study of Sprenger and Wernli (2003) showing that the lower tropospheric compositions of the Eastern Mediterranean region is favorable to stratosphere-to-troposphere transport events.

\subsection{Impact of ozone lateral boundaries on surface ozone}

Ozone lateral boundary concentrations were increased first by $5 \%$ and then $20 \%$ in order to study the system's response to perturbations of different magnitudes. Figure 11 shows the change in surface ozone by a $2 \mathrm{ppb}$ increase in ozone lateral boundaries. The most sensitive area to the response of increased ozone in the boundaries for both seasons is the north western part of the domain over the Atlantic, Great Britain and the western part of Scandinavia. This feature can be explained by the prevailing westerlies carrying along the excess of lateral ozone to the neighboring to the west boundary areas. The impact in surface ozone fades towards central Europe. The increase of ozone over central continental Europe is about $0.5 \mathrm{ppb}$ in winter and even less in summer and negligible over the Mediterranean during the warm months. A four time stronger perturbation of the $\mathrm{O}_{3}$ lateral boundaries 

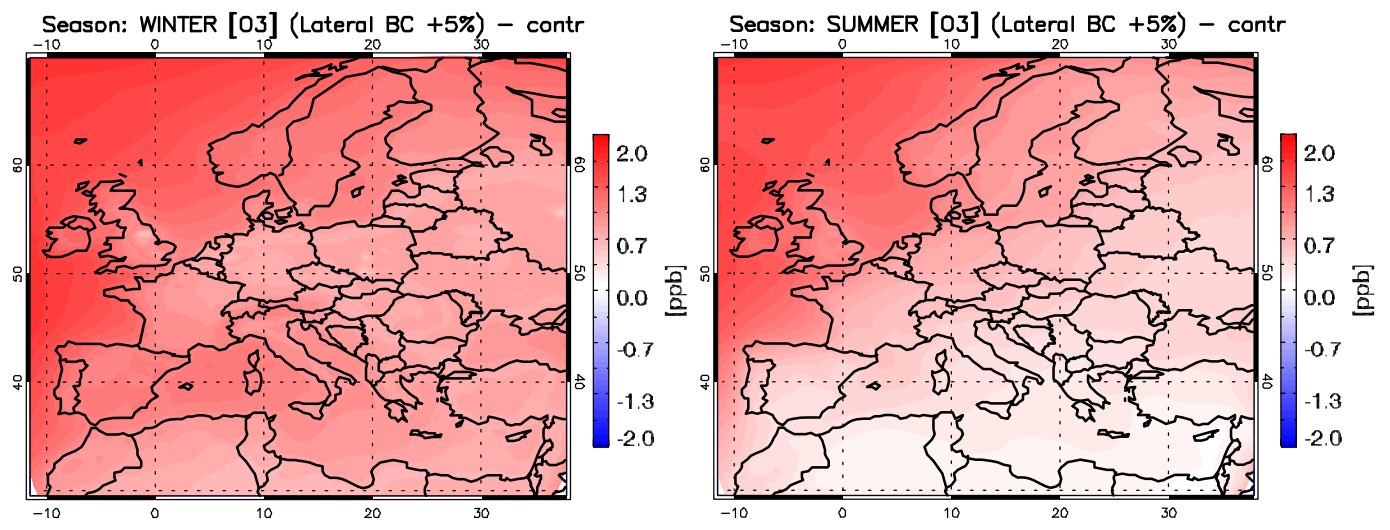

Fig. 11. Sensitivity study with $5 \% \mathrm{O}_{3}$ increase at the lateral boundary conditions. The plots show changes in seasonal average surface ozone concentrations for the winter (left) and the summer (right) season.
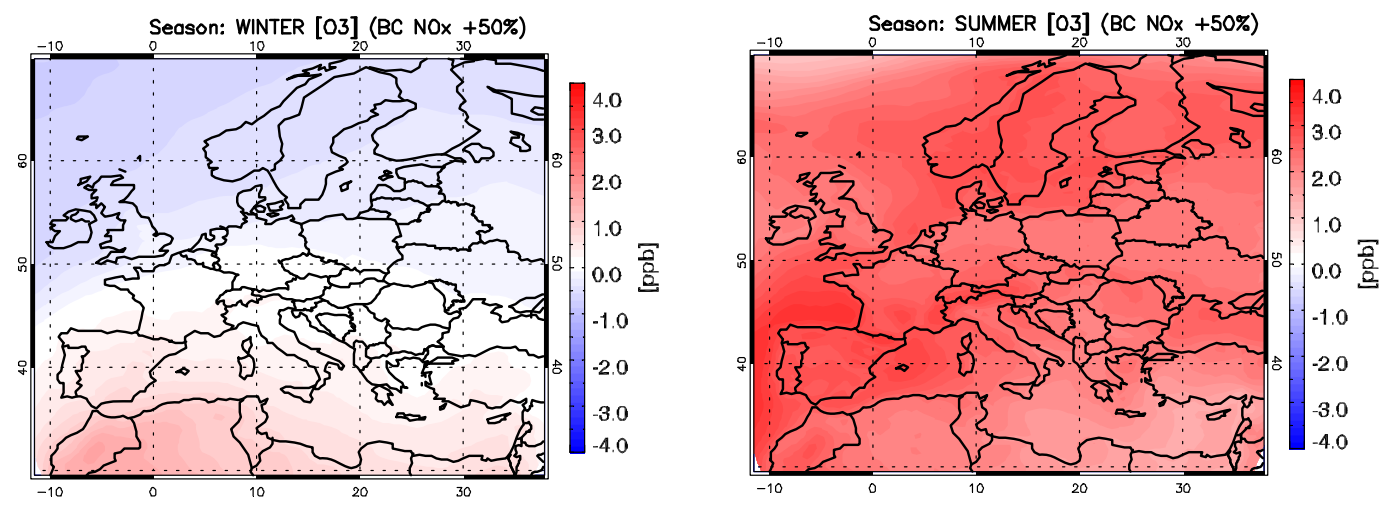

Fig. 12. Sensitivity studies with $50 \% \mathrm{NO}_{\mathrm{x}}$ increase in the lateral boundary conditions. The plots show changes in seasonal average surface ozone concentrations for the winter (left) and the summer (right) season.

(8 $\mathrm{ppb}$ ) attempted in the third sensitivity study, showed a four times increased signal over the European domain, with the same spatial pattern. Surface ozone concentrations increase by 7-8 ppb in the north western part of our domain (eastern Atlantic), around 3-4 ppb over Great Britain and western Scandinavia, and the impact fades out towards the south eastern part of Europe and the Mediterranean (not shown). This result highlights the sensitivity of north-western continental Europe on pre-defined boundaries used, when dynamic boundaries from a global model is not an option.

\subsection{Impact of $\mathrm{NO}_{\mathrm{x}}$ lateral boundaries on surface ozone}

In the last sensitivity study the $\mathrm{NO}_{\mathrm{x}}$ boundaries are increased by $1 \mathrm{vppb}\left(0.5 \mathrm{ppb} \mathrm{NO} \mathrm{N}_{2}\right.$ and $\left.0.5 \mathrm{ppb} \mathrm{NO}\right)$. The impact on surface ozone is shown in Fig. 12 and is obviously very much dependent on season. The impact of increased $\mathrm{NO}_{\mathrm{x}}$ is very small over continental Europe in winter and located in the inflow boundaries. In northern Europe where temperatures are low the there is not sufficient solar radiation for ozone production, the addition of NO leads to ozone loss and thus decrease of surface ozone. Higher temperature in the southern part of the domain lead to small ozone production, which is however marginal and not sufficient to transport surface ozone in the higher latitudes. On the contrary, during summer the meteorology is such that facilitates the abundant ozone production, so that the excess of ozone is transported over the whole domain and so the impact on surface ozone is homogenized over the whole domain. Surface ozone in summer is increased by about $3 \mathrm{vppb}$ over the whole domain due to changes in the $\mathrm{NO}_{\mathrm{x}}$ boundaries.

\section{Conclusions}

In this work a modeling system based on the air quality model CAMx driven off-line by the regional climate model RegCM was used for assessing the impact of different meteorological forcing on surface ozone over Europe for the decade 1991-2000. For the external meteorological forcing two different datasets were used: the ERA40 global atmospheric reanalysis dataset and the model output from the 
GCM ECHAM (ERA and ECHAM runs respectively). The focus of this work was to compare the perfect lateral boundary conditions experiment with the GCM driven experiment and to investigate how this external meteorological forcing affects near surface ozone.

Different RegCM forcings result in $\Delta\left(\mathrm{O}_{3}\right)$ ranging between $\pm 4 \mathrm{ppb}$, while all model parameterizations and anthropogenic emissions remain unchanged. The area showing the greatest sensitivity in $\mathrm{O}_{3}$ during winter is central and southern Europe while in summer is central north continental Europe. As indicated by the $500 \mathrm{hPa} \mathrm{GH}$, used here as an index of atmospheric circulation, the ECHAM run reveals a more steep GH gradient along the west-east axis of Europe and more anticyclonic conditions over Russia during summer. The differences in both zonal and meridional wind fields are associated with the differences in the circulation patterns. Furthermore, the differences in near surface air temperature and incoming solar radiation follow the differences in atmospheric circulation.

The results of our simple statistical model suggest that the changes in surface ozone can be predicted better during summer than during winter, knowing only the changes in meteorological variables. It succeeds to account for $62 \%$ of the variance in the predicted variable in summer and up to $26 \%$ in winter. Solar radiation changes explains a $33 \%$ of the $\Delta\left(\mathrm{O}_{3}\right)$ variance followed by geopotential height which explains almost $12 \%$ in warm months.

For comparison reasons, the impact of chemical boundary conditions on surface ozone was additionally examined with a series of sensitivity studies, showing that surface ozone changes are comparable to those caused by the different meteorological forcing. This finding highlights the strong impact of external meteorological forcing both on the final climatic and the coupled air quality information delivered. Special attention should be, thus, given to the selection of meteorological forcing besides the chemical boundaries, when regional climate-air quality studies are performed.

More in detail, four sensitivity studies were conducted, corresponding to a 5\% and 20\% increase of ozone in lateral boundaries, a $20 \%$ increase of ozone in top boundary, and a $50 \%$ increase of $\mathrm{NO}_{\mathrm{x}}$ lateral boundaries, in order to assess the impact of boundary conditions on surface ozone. The results show that the impact of ozone lateral boundaries is mostly seen over the western and north part of our domain. A perturbation of $2 \mathrm{ppb}$ in ozone lateral boundaries increases surface ozone concentrations by about $1 \mathrm{ppb}$ in the north west Europe (Great Britain an western Scandinavia) and the impacts fades out moving towards central and southern Europe. Increase of the perturbation by a factor of 4 , leads to a four times stronger impact on surface ozone with the same spatial pattern. The impact of increased $\mathrm{NO}_{\mathrm{x}}$ lateral boundaries on surface ozone is very much seasonal dependent. In the winter the impact is located near the inflow boundaries and is relatively small. In summer the meteorology facilitates ozone production, which is abundant and transports over the whole European domain, increasing ozone by about $3 \mathrm{ppb}$. Finally, the impact of ozone top boundary on surface ozone was shown to be mainly located over southern Europe, the magnitude of the perturbation was however, considerably smaller than the perturbation.

Acknowledgements. This work has been funded by the European Community's Sixth Framework Programme as part of the project CECILIA (Central and Eastern Europe Climate Change Impact and Vulnerability Assessment) under Contract No. 037005 and partially supported by the programme "Informacni spolecnost" No. 1ET400300414 and Research Plan of MSMT under No. MSM 0021620860. The authors acknowledge the anonymous referees and J. W. Kaminski for their useful comments.

Edited by: R. Vautard

\section{References}

Andreani-Aksoyoglu, S., Keller, J., Prévôt, A. S. H., Baltensperger, U., and Flemming, J.: Secondary aerosols in Switzerland and northern Italy: Modeling and sensitivity studies for summer 2003, J. Geophys. Res., 113(6), D06303, doi:10.1029/2007JD009053, 2008.

Baertsch-Ritter, N., Keller, J., Dommen, J., and Prévôt, A. S. H.: Effects of various meteorological conditions and spatial emissionresolutions on the ozone concentration and ROG/NO $\mathrm{xim}$ itationin the Milan area (I), Atmos. Chem. Phys., 4, 423-438, doi:10.5194/acp-4-423-2004, 2004.

Bloomfield, P., Royle, J. A., Steinberg, L. J., and Yang, Q.: Accounting for meteorological effects in measuring urban ozone levels and trends, Atmos. Environ., 30(17), 3067-3077, 1996.

Broennimann, S. and Neu, U.: Weekend-weekday differences of near-surface ozone concentrations in Switzerland for different meteorological conditions, Atmos. Environ., 31(8), 1127-1135, 1997.

Crutzen, P. J.: Tropospheric ozone: An overview, in "Tropospheric Ozone", edited by: Isaksen, I. S. A., D. Reidel Publ. Co., 3-32, 1988.

Davies, T. D., Kelly, P. M., Low, P. S., and Pierce, C. E.: Surface ozone concentrations in Europe: links with regional-scale atmospheric circulation, J. Geophys. Res., 97(9), 819-832, 1992.

Davis, J. M., Eder, B. K., Nychka, D., and Yang, Q.: Modeling the effects of meteorology on ozone in Houston using cluster analysis and generalized additive models, Atmos. Environ., 32(14/15), 2505-2520, 1998.

Dawson, J. P., Adams, P. J., and Pandis, S. N.: Sensitivity of ozone to summertime climate in the eastern USA: A modeling case study, Atmos. Environ., 41, 1494-1511, 2007.

Dawson, J. P., Racherla, P. N., Lynn, B. H., Adams, P. J., and Pandis, S. N.: Impacts of climate change on regional and urban air quality in the eastern United States: Role of meteorology, J. Geophys. Res., 114, D05308, doi:10.1029/2008JD009849, 2009.

Dickinson, R., Henderson-Sellers, A., and Kennedy, P. J.: Biosphere-Atmosphere Transfer Scheme, BATS: version1E as coupled to the NCAR Community Climate Model, NCAR Technical Note No NCAR/TN-387+STR, Boulder, CO, 72 pp, (avail- 
able from the National Center for Atmospheric Research, P.O. Box 3000, Boulder, CO 80307), 1993.

Diffenbaugh, N.S., Pal, J.S., Trapp, R.J., Giorgi, F.: Fine scale processes regulate the response of extreme events to global climate change. In: Proceedings of the National Academy of Sciences of the United States of America, vol. 102, pp. 15774-15778, 2005.

Dutilleul P.: Modifying the t Test for Assessing the Correlation Between Two Spatial Processes, Biometrics, 49, 305-314, 1993.

ENVIRON, CAMx User's Guide, Comprehensive Air Quality model with Extentions, version 4.40, www.camx.com, 2006.

Fiore, A. M., Horowitz, L. W., Purves, D. W., Levy, H., Evans, M. J., Wang, Y., Li, Q., and Yantosca, R. M.: Evaluating the contribution of changes in isoprene emissions to surface ozone trends over the eastern United States, J. Geophys. Res., 110, D12303, doi:10.1029/2004JD005485, 2005.

Francisco, R. V., Argete, J., Giorgi, F., Pal, J., Bi, X., and Gutowski, W. J.: Regional model simulation of summer rainfall over the Philippines, Theor. Appl. Climatol., 86, 215-227, 2006.

Fritsch, J. M. and Chappell, C. F.: Numerical prediction of convectively driven mesoscale pressure systems, Part I: Convective parameterization, J. Atmos. Sci., 37, 1722-1733, 1980.

Fuhrer, J. and Booker, F.: Ecological issues related to ozone: agricultural issues, Environ. Int. 29(2-3), 141-154, 2003.

Gao, X., Pal, J. S., and Giorgi, F.: Projected changes in mean and extreme precipitation over the Mediterranean region from high resolution double nested RCM simulations, Geophys. Res. Lett. 33, L03706, 2006.

Giorgi, F., Marinucci, M. R., and Visconti, G.: A 2XCO2 climate change scenario over Europe generated using a limited area model nested in a general circulation model, II: climate change scnario. J. Geophys. Res., 97, 10028-19911, 1992.

Giorgi, F., Bates, G. T., and Nieman, S. J.: The multi-year surface climatology of a regional atmospheric model over the western United States, J. Climate 6, 75-95, 1993a.

Giorgi, F., Marinucci, M. R., Bates, G. T., and DeCanio: G. Development of a second generation regional climate model (RegCM2), Part I: boundary layer and radiative transfer processes, Mon Weather Rev., 121, 2794-2813, 1993 b.

Giorgi, F. and Mearns, L. O.: Introduction to special section: regional climate modelling revisited, J. Geophys. Res., 104, 63356352, 1999.

Giorgi, F., Bi, X., and Qian, Y.: Direct radiative forcing and regional climatic effects of anthropogenic aerosols over East Asia, A regional coupled climate-chemistry/aerosol model study, J. Geophys. Res., 107, 4439, doi:10.1029/2001JD001066, 2002.

Giorgi, F., Bi, X., and Qian, Y.: Indirect vs. direct effects of anthropogenic sulfate on the climate of East Asia as simulated with a regional coupled climate-chemistry/aerosol model, Clim. Change, 58, 345-376, 2003.

Giorgi, F., X, Bi., and Pal, J.: Mean, interannual variability and trends in a regional climate change experiment over Europe, II: present day climate (1960-1990), Clim. Dynam., 22, 733-756, 2004a.

Giorgi, F., Bi, X., and Pal, J.: Mean, interannual variability and trends in a regional climate change experiment over Europe, I: climate change scenarios (2071-2100), Clim. Dynam., 23, 839858, 2004b.

Giorgi, F., Pal, J. S., Bi, X., Sloan, L., Elguindi, N., and Solmon, F.: Introduction to the TAC special issue: The RegCNET network,
Theor. Appl. Climatol., 86, 1-4, 2006.

Grell, G. A.: Prognostic evaluation of assumptions used by cumulus parametrizations, Mon. Weather Rev., 121, 764-787, 1993.

Grell, G. A., Dudhia, J., and Stauer, D. R.: A description of the fifthgeneration penn state/ncar mesoscale model (mm5). Technical report NCAR/TN-398+STR, National Center for Atmospheric Research, 1994.

Guenther, A. B., Zimmermann, P. C., Harley, R., Monson, R. K., and Fall, R.: Isoprene and monoterpene emission rate variability: model evaluations and sensitivity analyses, J. Geophys. Res., 98, 12609-12617, 1993.

Hauglustaine, D. A., Lathiere, J., Szopa, S., and Folberth, G. A.: Future tropospheric ozone simulated with a climatechemistry biosphere model, Geophys. Res. Lett., 32, L24807, doi:10.1029/2005GL024031, 2005.

Hedegaard, G. B., Brandt, J., Christensen, J. H., Frohn, L. M., Geels, C., Hansen, K. M., and Stendel, M.: Impacts of climate change on air pollution levels in the Northern Hemisphere with special focus on Europe and the Arctic, Atmos. Chem. Phys., 8, 3337-3367, doi:10.5194/acp-8-3337-2008, 2008.

Hegarty J., Mao, H., and Talbot, R.: Synoptic controls on summertime surface ozone in the northeastern United States, J. Geophys. Res., 112, D14306, doi:10.1029/2006JD008170, 2007.

Hewitt, C. D. and Griggs, D. J.: Ensembles-based predictions of climate changes and their impacts, EOS 85:566, 2004.

Hirakuchi, H. and Giorgi, F.: Multi year present day and 2XCO2 simulations of monsoon-dominated climate over Eastern Asia and Japan with a regional climate model nested in a general circulation model, J. Geophys. Res., 100, 21105-21126, 1995.

Hostetler, S. W., Giorgi, F., Bates, G. T., and Bartlein, P. J.: The role of lake-atmosphere feedbacks in sustaining paleolakes Bonneville and Lahontan 18,000 years ago, Science, 263, 665-668, 1994.

Im, E.-S., Park, E.-H., Kwon, W.-T., and Giorgi, F.: Present climate simulation over Korea with a regional climate model using a oneway double-nested system, Theor. Appl. Climatol., 86, 187-200, 2006.

Intergovernmental Panel on Climate Change (IPCC), Climate Change 2007: The Physical Science Basis, 996 pp., Cambridge Univ. Press, New York, 2007.

Ito, A., Sillman, S., and Penner, J. E.: Global chemical transport model study of ozone response to changes in chemical kinetics and biogenic volatile organic compounds emissions due to increasing temperatures: Sensitivities to isoprene nitrate chemistry and grid resolution, J. Geophys. Res., 114, D09301, doi:10.1029/2008JD011254, 2009.

Jacob, D. J. and Winner, D. A.: Effect of climate change on air quality, Atmos. Environ., 43(1), 51-63, 2009.

Kalabokas, P. D., Mihalopoulos, N., Ellul, R., Kleanthous, S., and Repapis, C. C.: An investigation of the meteorological and photochemical factors influencing the background rural and marine surface ozone levels in the Central and Eastern Mediterranean, Atmos. Environ., 42, 7894-7906, doi:10.1016/j.atmosenv.2008.07.009, 2008.

Khalid, I. A.-W. and Samson, P. J.: Preliminary sensitivity analysis of Urban Airshed Model simulations to temporal and spatial availability of boundary layer wind measurements, Atmos. Environ., 30(12), 2027-2042, 1996. 
Kiehl, J. T., Hack, J. J., Bonan, G. B., Boville, B. A., Breigleb, B. P., Williamson, D., and Rasch, P.: Description of the ncar community climate model (ccm3), Tech. Rep. NCAR/TN-420+STR, National Center for Atmospheric Research, 1996.

Krüger B. C, Katragkou, E., Tegoulias, I., Zanis, P., Melas, D., Coppola, E., Rauscher, S., Huszar, P., and Halenka, T.: Regional photochemical model calculations for Europe concerning ozone levels in a changing climate, Quarterly Journal of the Hungarian Meteorological Service, 112(3-4), 285-300, 2008.

von Kuhlmann, R., Lawrence, M. G., Pöschl, U., and Crutzen, P. J.: Sensitivities in global scale modeling of isoprene, Atmos. Chem. Phys., 4, 1-17, doi:10.5194/acp-4-1-2004, 2004.

Lee, S.-M., Princevac, M., Mitsutomi, S., and Cassmassi, J.: MM5 simulations for air quality modeling: An application to a coastal area with complex terrain Atmos. Environ., 43(2), 447-457, 2009.

Lei, W., de Foy, B., Zavala, M., Volkamer, R., and Molina, L. T.: Characterizing ozone production in the Mexico City Metropolitan Area: a case study using a chemical transport model, Atmos. Chem. Phys., 7, 1347-1366, doi:10.5194/acp-7-1347-2007, 2007.

Li, Q., Jacob, D. J., Bey, I., Palmer, P. I., Duncan, B. N., Field, B. D., Martin, R. V., Fiore, A. M., Yantosca, R. M., Parrish, D. D., Simmonds, P. G., and Oltmans, S. J.: Transatlantic transport of pollution and its effects on surface ozone in Europe and North America, J. Geophys. Res.-Atmos., 107(13), 4-1-4-21, 2002.

Meehl, G. A., Covey, C., Delworth, T., Latif, M., McAvaney, B., Mitchell, J. F. B., Stouffer, R. J., and Taylor, K. E.: THE WCRP CMIP3 Multimodel Dataset: A New Era in Climate Change Research, B. Am. Meteorol. Soc., 88(9), 1383-1394, 2007.

Meleux, F., Solmon, F., and Giorgi, F.: Increase in summer European ozone amounts due to climate change, Atmos. Environ., 41(35), 7577-7587, 2007.

Nolte C. G., Gilliland, A. B., Hogrefe, C., and Mickley L. J.: Linking global to regional models to assess future climate impacts on surface ozone levels in the United States. J. Geophys. Res., 113, D14307, doi:10.1029/2007JD008497, 2008.

Pal, J. S., Small, E. E., and Eltahir, E. A. B.: Simulation of regionalscale water and energy budgets:Representation of subgrid cloud and precipitation processes within RegCM, J. Geophys. Res., 105(D24), 29579-29594, 2000.

Penkett, S. A.: Indications and causes of ozone increase in the troposphere, in "The changing atmosphere", edited by: Rowland, F. S. and Isaksen, I. S. A., J. Wiley \& Sons, 91, 1988.

Racherla, P. N. and Adams, P. J.: Sensitivity of global tropospheric ozone and fine particulate matter concentrations to climate change, J. Geophys. Res., 111, D24103, doi:10.1029/2005JD006939, 2006.

Racherla, P. N. and Adams, P. J.: The response of surface ozone to climate change over the Eastern United States, Atmos. Chem. Phys., 8, 871-885, doi:10.5194/acp-8-871-2008, 2008.

Rauscher S. A., Coppola, E., Piani, C., and Giorgi, F.: Resolution effects on regional climate model simulations of seasonal precipitation over Europe, Clim. Dynam., 35(4), 685-711, doi:10.1007/s00382-009-0607-7, 2010.

Roeckner, E., Bäuml, G., Bonaventura, L., Brokopf, R., Esch, M., Giorgetta, M., Hagemann, S., Kirchner, I., Kornblueh, L., Manzini, E., Rhodin, A., Schlese, U., Schulzweida, U., and Tompkins, A.: The atmospheric general circulation model
ECHAM5, Part I: Model description, Max Planck Institute for Meteorology Rep. 349, 127 pp., edited by: Sanchez-Gomez, E., Somot, S., and Déqué, M., 2009, Ability of an ensemble of regional climate models to reproduce weather regimes over Europe-Atlantic during the period 1961-2000, Clim. Dynam., 33(5), 723-736, 2003.

Scebba, F., Giuntini, D., Castagna, A., Soldatini, G., and Ranieri, A.: Analysing the impact of ozone on biochemical and physiological variables in plant species belonging to natural ecosystems, Environ. Exp. 1 Bot., 235-246, 2005.

Schlink U., Herbarth, O., Richter, M., Dorling, S., Nunnari, G., Cawley, G., and Pelikan, E.: Statistical models to assess the health effects and to forecast ground-level ozone, Environ. Modell. Soft., 21(4), 547-558, 2006.

Seinfeld, J. H. and Pandis, S. N.: Atmospheric Chemistry and Physics, John Wiley, 3rd Ed., U.S.A., 1998.

Seth, A. and Rojas, M.: Simulation and sensitivity in a nested modeling system for South America, Part I: reanalyses boundary forcing, J. Climate, 16, 2437-2453, 2003.

Sillman, S. and Samson, P. J.: Impact of temperature on oxidant photochemistry in urban, polluted rural and remote environments, J. Geophys. Res., 100(D6), 11497-11508, 1995.

Simpson, D., Winiwarter, W., Börjesson, G., Cinderby, S., Ferreiro, A., Guenther, A., Hewitt, C. N., Janson, R., Khalil, M. A. K., Owen, S., Pierce, T. E., Puxbaum, H., Shearer, M., Skiba, U., Steinbrecher, R., Tarrasón, L., and Öquist, M. G.: Inventorying emissions from nature in Europe, J. Geophys. Res., 104(D7), 8113-8152, 1999.

Small, E. E., Giorgi, F., and Sloan, L. C.: Regional climate model simulation of precipitation in Central Asia: mean and interannual variability, J. Geophys. Res., 104, 6563-6582, 1999.

Sprenger, M. and Wernli, H.: A northern hemispheric climatology of cross-tropopause exchange for the ERA15 time period (1979-1993), J. Geophys Res., 108(D12), 8521, doi::10.1029/2002JD002636, 2003.

Stevenson, D. S., Dentener, F. J., Schultz, M. G., Ellingsen, K., van Noije, T. P. C., Wild, O., Zeng, G., Amann, M., Atherton, C. S., Bell, N., and Bergmann, D. J.: Bey, Multimodel ensemble simulations of present-day and near-future tropospheric ozone, J. Geophys. Res., 111, D08301, doi:10.1029/2005JD006338, 2006.

Sun, L., Semazzi, F. H. M., Giorgi, F., and Ogallo, L.: Application of the NCAR regional climate model to eastern Africa. Part II: simulation of interannual variability of the short rains, J. Geophys. Res., 104, 6549-6565, 1999.

Szopa, S., Hauglustaine, D. A., Vautard, R., and Menut, L., Future global tropospheric ozone changes and impact on European air quality, Geophys. Res. Lett., 33, L18805, doi:10.1029/2006GL25860, 2006.

Tang, Y., Carmichael, G. R., Thongboonchoo, N., Chai, T., Horowitz, L. W., Pierce, R. B., Al-Saadi, J. A., Pfister, G., Vukovich, J. M., Avery, M. A., Sachse, G. W., Ryerson, T. B., Holloway, J. S., Atlas, E. L., Flocke, F. M., Weber, R. J., Huey, L. G., Dibb, J. E., Streets, D. G., and Brune, W. H.: Influence of lateral and top boundary conditions on regional air quality prediction: A multiscale study coupling regional and global chemical transport models, J. Geophys. Res., 112, D10S18, doi:10.1029/2006JD007515, 2007.

Uppala, S. M., Kallberg, P. W., Simmons, A. J., Andrae, U., da Costa Bechtold, V., Fiorino, M., Gibson, J. K., Haseler, J., Her- 
nandez, A., Kelly, G. A., Li, X., Onogi, K., Saarinen, S., Sokka, N., Allan, R. P., Andersson, E., Arpe, K., Balmaseda, M.A., Beljaars, A. C. M., van de Berg, L., Bidlot, J., Bormann, N., Caires, S., Chevallier, F., Dethof, A., Dragosavac, M., Fisher, M., Fuentes, M., Hagemann, S., Holm, E., Hoskins, B. J., Isaksen, L., Janssen, P. A. E. M., Jenne, R., McNally, A. P., Mahfouf, J.-F., Morcrette, J.-J., Rayner, N. A., Saunders, R. W., Simon, P., Sterl, A., Trenberth, K. E., Untch, A., Vasiljevic, D., Viterbo, P., and Woollen, J.: The ERA-40 re-analysis, Quart. J. Royal Meteorol. Soc. 131, 2961-3012, 2005.
Vestreng, V., Breivik, K., Adams, M., Wagener, A., Goodwin, J., Rozovskaya, O., Pacyna, J. M.: Inventory Review 2005, Emission Data reported to LRTAP Convention and NEC Directive, Initial review of HMs and POPs, Technical report MSC-W 1/2005, ISSN 0804-2446, 2005.

Winiwarter, W. and Zueger, J.: Pannonisches Ozonprojekt, Teilprojekt Emissionen. Endbericht. Report OEFZS-A-3817, Austrian Research Center, Seibersdorf, 1996.

Zeng, X., Zhao, M., and Dickinson, R. E.: Intercomparison of bulk aerodynamic algorithms for the computation of sea surface fluxes using toga coare and tao data, J. Climate, 11, 2628-2644, 1998. 